\title{
Receiving a diagnosis of young onset dementia: a scoping review of lived experiences
}

Mary O'Malley ${ }^{\mathrm{a}}$, Janet Carter ${ }^{\mathrm{b}}$, Vasileios Stamou ${ }^{\mathrm{c}}$, Jenny LaFontaine ${ }^{\mathrm{c}}$, Jan Oyebode $^{c}$, and Jacqueline Parkes ${ }^{\text {a* }}$

${ }^{a}$ Faculty of Health and Society, University of Northampton, Northampton, NN1 5PH;

${ }^{b}$ Division of Psychiatry, Maple House, London, WIT $7 N F$; ${ }^{c}$ Centre for Applied Dementia Studies, University of Bradford, Bradford BD7 IDP

Provide full correspondence details here including e-mail for the *corresponding author: Jacqueline Parkes; Jacqueline.parkes@northampton.ac.uk

Provide short biographical notes on all contributors here if the journal requires them. 


\section{Receiving a diagnosis of young onset dementia: a scoping review of lived experiences}

Objectives: The personal experience of receiving a diagnosis of young onset dementia (YOD) is often overlooked in a complex assessment process which can require substantial investigation. This review comprises a thematic synthesis of qualitative studies published until November 2018 that capture the lived experience of younger people undergoing assessment and receiving a diagnosis of dementia. This was conducted to inform a Delphi study with younger people with dementia about improving the diagnostic process to identify the strengths and weaknesses of current approaches and help educate professionals about key issues.

Method: Systematic searches of appropriate bibliographic databases were conducted to collate literature involving self-reported experiences of diagnosis of YOD. Eight out of 47 initially-identified papers satisfied our search term criteria, and all papers were quality assessed using Walsh \& Browne’s criteria for methodological appraisal.

Results: The review of the literature emphasises that delays in diagnosis can often be attributed to (1) delays in accessing help by the younger person, and (2) misattribution of symptoms by the clinician. The impact of diagnosis is influenced by the language used by the clinician, and reactions to the diagnosis vary from feelings of reassurance, to shock and destabilisation.

Conclusion: Understanding the perspective of a younger person undergoing assessment for dementia is important both in terms of promoting future engagement with services and in designing and evaluating interventions to improve the diagnostic process. This review suggests that improving the recognition of presenting symptoms, reducing diagnostic errors and identifying the emotional needs arising from diagnosis are required to improve the diagnostic experience for younger adults.

Keywords: word; another word; lower case except names

Subject classification codes: include these here if the journal requires them 


\section{Background}

The process of being assessed and receiving a diagnosis of dementia can be long and daunting (Vernooij-Dassen, 2006). This is particularly true for younger individuals (Svanberg, Spector, \& Stott, 2011; van Vliet et al., 2013) as dementia is typically underrecognised in this age group and often requires more complex investigation. Approximately 42,325 people living in the UK have a diagnosis of YOD (Dementia UK Update, 2014), with an estimated incidence of 11.5 YOD cases per 100,000 people (Mercy, Hodges, Dawson, Barker, \& Brayne, 2008).

Research that has involved younger people living with dementia has predominantly focused on epidemiological studies (Harvey, Skelton-Robinson, \& Rossor, 2003) and their clinical or service needs (Mayrhofer, Mathie, McKeown, Bunn, \& Goodman, 2018; Roach, Keady, \& Bee, 2012). More recently, it has been emphasised that people living with dementia should be given the right to speak about their experiences (Rohra, 2016) and be listened to (JonasSimpson, 2003). A greater understanding of the experience younger adults encounter, including identifying challenging barriers during the diagnostic process, could help to provide a more person-centred diagnostic approach for younger adults.

Young onset dementia (YOD) is typically more complex to diagnose than late onset dementia as presentations are likely to be of rare cause disorders and the common dementias frequently present with atypical symptoms (Rosness, Engedal, \& Chemali, 2016; Rossor, Fox, Mummery, Schott, \& Warren, 2010; Vieira et al., 2013). The increased frequency of first presentation to services being with symptoms other than memory loss means that misdiagnoses due to other causes, such as psychiatric disorders, depression, and other 
neurological illness (Vieira et al., 2013), are common. Collectively, this may lead to prolonged delays in receiving a confirmed diagnosis (Draper et al., 2016), significant uncertainty for families and delay in accessing suitable support (Williams, Dearden, \& Cameron, 2001) for individuals and their families. These issues could be mitigated by more timely and accurate diagnoses and increased sensitivity from clinicians when discussing and delivering the diagnosis (Sansoni et al., 2016; Millenaar et al 2016).

Advocates for YPD have shared the personal experiences that they encountered during their own diagnosis. These include a prior (mis)diagnosis of burnout and depression (Rohra, 2016) resulting in unnecessary delay and a 'feeling of unexpectedness' when the diagnosis was formally confirmed (Greenwood \& Smith, 2016; Harris, 2004; Pamela. Roach, Drummond, \& Keady, 2016). Rohra describes “(I) saw myself on a slide that descended into a black tunnel, down and down ... I began to cry" (page 42, Rohra, 2016). On the other hand, Kate Swaffer, who is living with YOD, has argued that an early diagnosis can be regarded as empowering, enabling and assisting the individual to remain independent for longer (Swaffer, 2016).

Despite these highly valuable insights, there is no published evidence which focuses specifically on the personal experiences of younger people who ultimately receive a diagnosis of dementia, with respect to the challenges individuals have faced. This review aims to bring together qualitative self-reports from YPD on the journey to diagnosis to better understand both positive and negative experiences of diagnosis which could shape future guidance about best practice.

This review forms part of the evidence for ongoing research conducted by the authors, aimed at improving the quality of diagnosis for YPD (http://www.ucl.ac.uk/psychiatry/the-angela- 
project) in a national project called the Angela Project. Importantly, the findings from this review were used to derive a round 1 questionnaire for a national Delphi consensus study with people living with YOD and their family supporters on best ways to improve the diagnostic process.

The aims of this literature review were to (1) collate the existing research base regarding the self-reported experience of receiving a diagnosis of YOD and (2) to summarise the themes and patterns that emerged.

\section{Method}

A comprehensive search of the literature was conducted for a scoping review in May 2017 and then updated in November 2018 using two electronic search engines: PubMed and Web of Science. These databases were selected due to their specific focus on life sciences and biomedical fields of research. The focus was only on research articles that had been published in peer reviewed journals to ensure the studies used a robust and rigorous evidence base and methodology.

\section{Search Strategy:}

Systematic and concise terms were used during the search of relevant papers. A breakdown of the terminology used is summarised in Table XX. The terms in the groups were combined using the AND function in the following manner: 1 AND 2 AND 3 AND 4.

Group Terms (in title or abstract) 


\begin{tabular}{|c|c|}
\hline $\begin{array}{l}1-\text { defining } \\
\text { terms for young } \\
\text { onset }\end{array}$ & $\begin{array}{l}\text { TS=(("young onset" OR "younger onset" OR "early onset" OR } \\
\text { "presenile" OR "working age" OR "YOD” OR "under 65") NOT } \\
\text { ("elderly" OR "older" OR "late") }\end{array}$ \\
\hline $\begin{array}{l}2-\text { defining } \\
\text { terms for } \\
\text { dementia, and } \\
\text { individual } \\
\text { diagnoses }\end{array}$ & $\begin{array}{l}\text { TS=("dementia" AND "Alzheimer's" OR "vascular dementia" OR } \\
\text { "frontotemporal dementia" OR "Semantic dementia" OR "Huntington's } \\
\text { disease" OR "acquired brain injury" OR "Parkinson's disease" OR } \\
\text { "Creutzfeldt-Jakob" OR "CJD" OR "Lewy bodies" OR "Picks disease" } \\
\text { OR "cognitive impairment" OR "neurocognitive disorder" OR "Posterior } \\
\text { Cortical Atrophy") }\end{array}$ \\
\hline $\begin{array}{l}3-\text { defining } \\
\text { terms for the } \\
\text { diagnostic } \\
\text { process }\end{array}$ & $\begin{array}{l}\mathrm{TS}=(\text { (diagnosis" AND “assessment" OR “diagnostic" OR "GP” OR } \\
\text { "misdiagnosis" OR "misdirection" OR "referral”) }\end{array}$ \\
\hline $\begin{array}{l}4-\text { defining } \\
\text { terms for lived } \\
\text { experiences }\end{array}$ & $\mathrm{TS}=$ ("experience" OR "Quality of Life") \\
\hline
\end{tabular}

Table 1: A breakdown of the four criteria and terms used when searching the search engines for appropriate articles.

\section{Additional inclusions}


Papers published until $30^{\text {th }}$ May 2017, with no date restrictions, were included in the comprehensive search. On 15th November 2018, the search was re-run and updated using the original search terms to establish if any additional papers had been published. Additionally, research studies conducted outside of the UK were included, however we only focused on articles written in English. Protocol-driven search strategies were supplemented with snowballing methods to search for additional relevant papers (Greenhalgh \& Peacock, 2005). These included reference list and citation searches, author searches, and hand searching of key journals.

\section{Exclusion criteria}

Papers meeting any of the following criteria were excluded:

- Studies involving non-primary neurodegenerative conditions, such as Korsakoff syndrome or an alcohol induced dementia, and HIV related cognitive impairment, as. individuals with these conditions traditionally have different pathways to care.

- Dementia research studies solely focused on late-onset dementia, as these would not reflect the experiences of people with YOD.

- Articles that were not peer reviewed.

\section{Inclusion criteria}

To be included papers needed to meet all the following criteria:

- Qualitative or mixed method research that directly involved people living with YOD.

- Investigations of the lived experiences of YOD and where themes surrounding diagnosis were reported. 
- Research that involved speaking directly to those affected by YOD (i.e. those diagnosed and/or their family members/carers).

- Articles were published in English.

\section{Procedures for Study Selection and Review}

Abstracts were retrieved, examined and reviewed for their relevance based on the inclusion criteria by one author (MOM), then considered and discussed during project meetings with two further team members (JC, JP). Full texts of articles were then retrieved and examined by three authors (MOM, JC and JP) in terms of their relevance.

\section{Quality Assessment}

A quality checklist with 12 criteria for qualitative research (Walsh \& Downe, 2006) was used to appraise the methodological quality of the studies. Papers were scored on 12 criterions. If the criterion was met, they rated with 1 , while those that did not meet the criterion were rated with 0 . If the criteria were half-met, the papers were rated with 0.5 , and N/A was used if the criteria were not applicable to the given study. This led to a final score out of 12 . The quality of the included studies was checked by one rater (MOM). Please see Table 2 for the table of quality assessment.

\section{Results}

\section{Search Results}

The search identified 47 research articles, of which 11 were included in the in-depth review using the criteria stated above. Eight of the 11 articles met the inclusion criteria. A 
breakdown of the stages involved in highlighting the appropriate papers for the review is summarised in Figure 1.

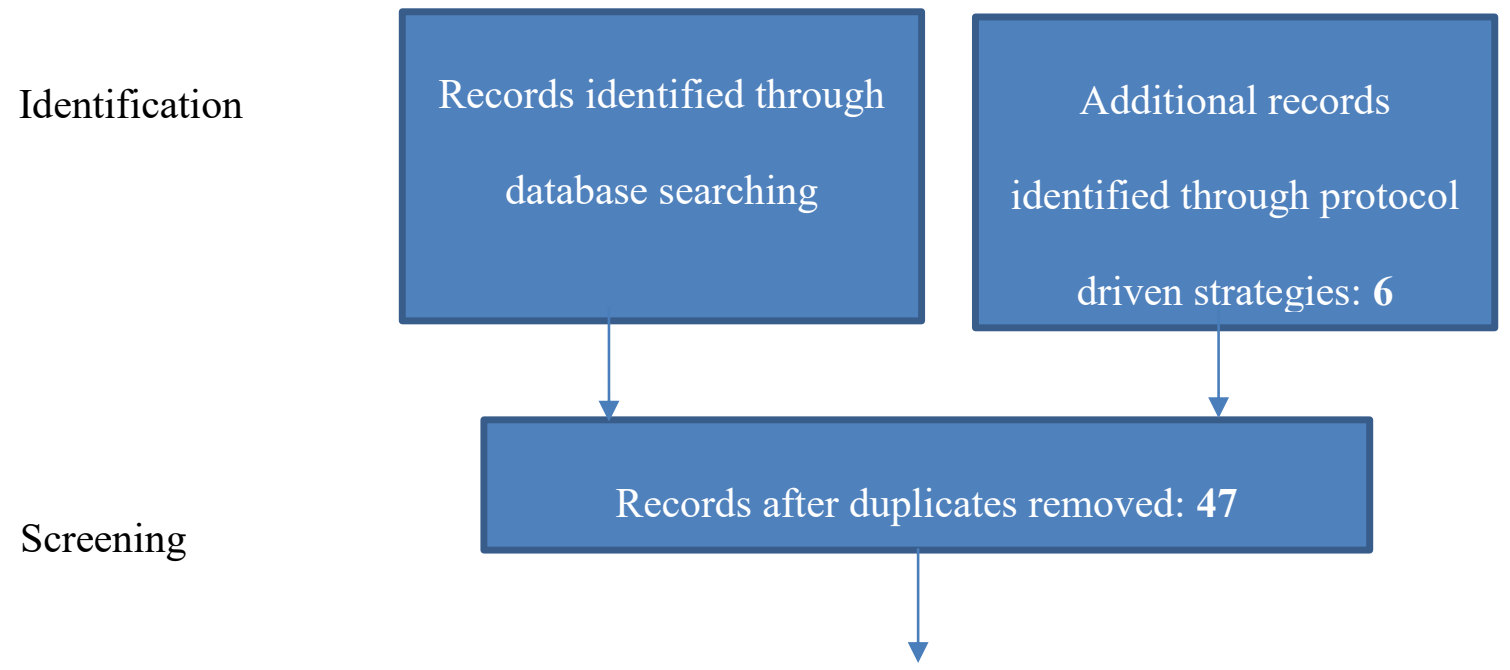

Eligibility

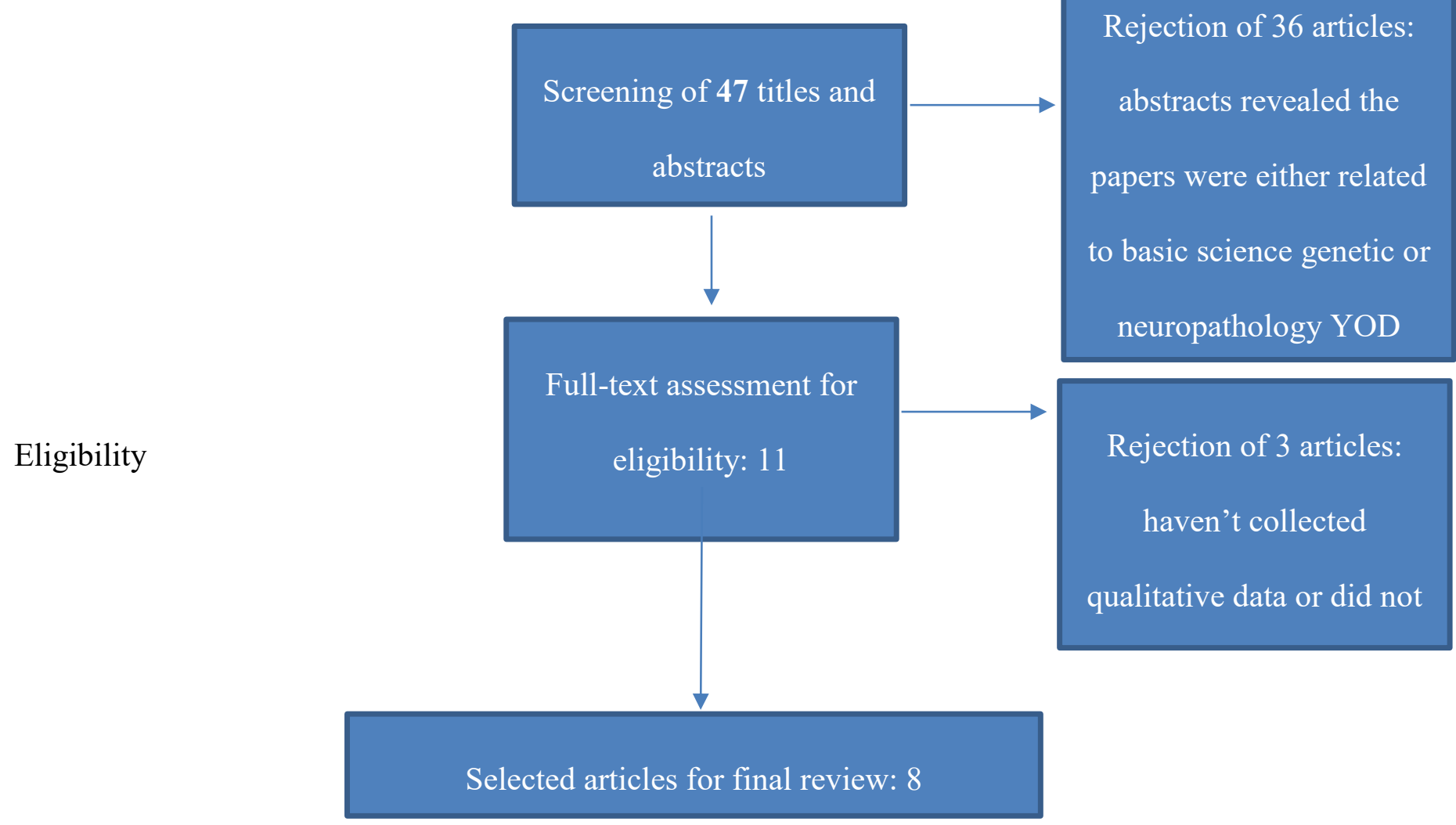

Inclusion 
Figure 1: PRISMA flowchart of the literature selection procedure (Moher, Liberati, Tetzlaff, \& Altman, 2010). 
Table 2 below shows the Quality Assessment of the included eight studies found in the literature search.

\begin{tabular}{|c|c|c|c|c|c|c|c|c|}
\hline & $\begin{array}{l}\text { Beatti } \\
e \\
(2004)\end{array}$ & $\begin{array}{l}\text { Griffin, } \\
\text { Oyebode } \\
\text { and Allen } \\
(2016)\end{array}$ & $\begin{array}{l}\text { Harri } \\
\text { s } \\
(2004 \\
)\end{array}$ & $\begin{array}{l}\text { Hoppe } \\
\text { (2017) }\end{array}$ & $\begin{array}{l}\text { Johannes } \\
\text { sen \& } \\
\text { Moeller } \\
(2013)\end{array}$ & $\begin{array}{l}\text { Rabanal et } \\
\text { al } 2018\end{array}$ & $\begin{array}{l}\text { Roach et al } \\
2016\end{array}$ & $\begin{array}{l}\text { Warwrziczn } \\
y \quad \text { et al } \\
(2016)\end{array}$ \\
\hline $\begin{array}{l}\text { Clear statement of, and rationale for, } \\
\text { research question, aims and purposes }\end{array}$ & 1 & 1 & 1 & 1 & 1 & 1 & 1 & 1 \\
\hline $\begin{array}{l}\text { Study thoroughly contextualised by existing } \\
\text { literature }\end{array}$ & 1 & 1 & 1 & 1 & 1 & 1 & 1 & 1 \\
\hline $\begin{array}{l}\text { Data collection strategy apparent and } \\
\text { appropriate }\end{array}$ & 1 & 1 & 1 & 1 & 0.5 & 1 & 1 & 1 \\
\hline $\begin{array}{l}\text { Method/design apparent, and consistent } \\
\text { with research interest }\end{array}$ & 1 & 0.5 & 1 & 0.5 & 0.5 & 1 & 1 & 1 \\
\hline Sample and sampling method appropriate & 0 & 1 & 0.5 & 1 & 0.5 & 1 & 1 & 0 \\
\hline Analytic approach appropriate & 1 & 0.5 & 0 & 0.5 & 1 & 1 & 1 & 1 \\
\hline $\begin{array}{l}\text { Context described and taken account of in } \\
\text { interpretation }\end{array}$ & 1 & 1 & 0.5 & 1 & 0.5 & 1 & 1 & 1 \\
\hline
\end{tabular}




\section{Clear audit trial given}

\section{Data used to support interpretation}

Researcher reflexivity

demonstrated

Demonstration of sensitivity to ethical considerations

Relevance and transferability evident

Total Score

Table 2: Quality Assessment of the included studies based on Walsh \& Downe's (2006) suggestions. $1=$ criterion met, $0.5=$ criterion partially

met, $0=$ criterion not met

$\begin{array}{llllllll}1 & 1 & 1 & 1 & 1 & 1 & 0.5 & 0.5 \\ 1 & 1 & 1 & 1 & 1 & 1 & 1 & 1 \\ 1 & 1 & 0.5 & 0.5 & 0.5 & 0.5 & 0.5 & 0.5 \\ 1 & 1 & 0.5 & 1 & 1 & 0.5 & 1 & 1 \\ 1 & 1 & 1 & 0.5 & 1 & 1 & 1 & 1 \\ 11 & 11 & 9 & 10 & 9.5 & 11 & 11 & 10\end{array}$


Table 3 below summarises the studies found in the literature search, providing quotes from those interviewed with a comment on our interpretation of the quotes, and the conclusions made by the authors. Studies have been ordered alphabetically according to the first author per study.

\begin{tabular}{|c|c|c|c|c|c|c|c|c|}
\hline Author/Year & Country & $\begin{array}{l}\text { Study } \\
\text { Population }\end{array}$ & $\begin{array}{l}\text { Diagnosis } \\
\text { of YPD }\end{array}$ & Measures & Quotes & \multicolumn{2}{|c|}{$\begin{array}{l}\text { Our interpretation of } \\
\text { quotes and findings }\end{array}$} & $\begin{array}{l}\text { Conclusions by } \\
\text { authors of paper }\end{array}$ \\
\hline $\begin{array}{l}\text { Beattie } \\
(2004)\end{array}$ & UK & $\begin{array}{l}\text { PwYOD } \\
(14): \quad \text { age: } \\
59.4 \text { years } \\
(41-66) ; \\
\text { gender: } 5 \\
\text { females, } 9 \\
\text { males }\end{array}$ & NS & $\begin{array}{l}\text { Semi- } \\
\text { structured } \\
\text { Interviews }\end{array}$ & $\begin{array}{l}\text { "'I went to [mentions four } \\
\text { different hospitals] and } \\
\text { had the scans. I went there } \\
\text { last November and I went } \\
\text { last January, this year, and } \\
\text { I should have heard from } \\
\text { [the hospitals] in June this } \\
\text { year, I should have went, } \\
\text { but I haven't heard } \\
\text { anything off them at all, } \\
\text { right.' (YP 6) } \\
\text { The diagnostic testing was } \\
\text { perceived as 'baffling', } \\
\text { which left one participant } \\
\text { (and carer) feeling } \\
\text { incompetent, distressed }\end{array}$ & $\begin{array}{l}\text { The quote by YP } \\
14 \text { highlights } \\
\text { how this } \\
\text { particular person } \\
\text { felt that the } \\
\text { diagnosis was } \\
\text { fed back in a } \\
\text { "brutal" manner } \\
\text { and was } \\
\text { perceived as } \\
\text { traumatic or } \\
\text { unempathic. }\end{array}$ & $\begin{array}{l}\text { The } \\
\text { the } \\
\text { that } \\
\text { expe } \\
\text { qual } \\
\text { post } \\
\text { lack } \\
\text { abou }\end{array}$ & $\begin{array}{l}\text { paper emphasises } \\
\text { delays to diagnosis } \\
\text { younger adults } \\
\text { erience, the poor } \\
\text { lity of information } \\
\text {-diagnosis, and the } \\
\text { of explanation } \\
\text { ut next steps. }\end{array}$ \\
\hline
\end{tabular}




\begin{tabular}{|c|c|c|c|c|c|c|c|}
\hline & & & & & $\begin{array}{l}\text { and unprepared for the } \\
\text { receipt of distressing news: } \\
\text { It was very blunt, yeah. It } \\
\text { was brutal, that's the only } \\
\text { word for it. (YP 14)'" }\end{array}$ & & \\
\hline $\begin{array}{l}\text { Griffin, } \\
\text { Oyebode, \& } \\
\text { Allen, (2016) }\end{array}$ & UK & $\begin{array}{l}\text { PwYOD } \\
\begin{array}{ll}(5): \text { age: } & 46 \\
- & 62 ; \\
\text { gender: } & 2 \\
\text { females, } & 3 \\
\text { males }\end{array}\end{array}$ & BvFTD & $\begin{array}{l}\text { Semi- } \\
\text { structured } \\
\text { Interviews }\end{array}$ & $\begin{array}{l}\text { "David explained that the } \\
\text { people in hospital with him } \\
\text { 'had problems with their } \\
\text { brains' but then continued } \\
\text { to say the doctor had said } \\
\text { he 'must have that [frontal- } \\
\text { temporal dementia] but I } \\
\text { haven't because they do } \\
\text { things wrong, but I don't } \\
\text { do things wrong.." }\end{array}$ & $\begin{array}{l}\text { This quote } \\
\text { highlighted a } \\
\text { difficulty in fully } \\
\text { understanding } \\
\text { the impact and } \\
\text { meaning of the } \\
\text { diagnosis by the } \\
\text { recipient. }\end{array}$ & $\begin{array}{l}\text { Following a diagnosis } \\
\text { of BvFTD, it was noted } \\
\text { that there was a lack of } \\
\text { emotional reaction and } \\
\text { reflection on the } \\
\text { diagnosis for one } \\
\text { recipient. } \\
\text { This may suggest } \\
\text { challenges in } \\
\text { connecting with the } \\
\text { meaning of the } \\
\text { information relayed, } \\
\text { seeing it as something } \\
\text { 'other' and not relevant } \\
\text { to own personal } \\
\text { experience, together }\end{array}$ \\
\hline
\end{tabular}




\begin{tabular}{|c|c|c|c|c|c|c|c|}
\hline & & & & & & & $\begin{array}{l}\text { with lack of insight. } \\
\text { This was particularly } \\
\text { when reflecting on the } \\
\text { meaning of the } \\
\text { dementia diagnosis } \\
\text { itself, as well as the } \\
\text { new change of lifestyle } \\
\text { as a result of the } \\
\text { dementia symptoms } \\
\text { and diagnosis. }\end{array}$ \\
\hline $\begin{array}{l}\text { Harris } \\
\text { (2004) }\end{array}$ & USA & $\begin{array}{l}\text { PwYOD } \\
\text { (23), age } 56 \\
\text { (43-68); } \\
\text { gender: } 13 \\
\text { females, } 10 \\
\text { males }\end{array}$ & $\begin{array}{ll}14 \text { AD, } & 6 \\
\text { FTD, } & 1 \\
\text { MCI, } & 1 \\
\text { HD. } & \end{array}$ & $\begin{array}{l}\text { Focus } \\
\text { groups, } \\
\text { face-to- } \\
\text { face } \\
\text { interviews, } \\
\text { and on-line } \\
\text { interviews }\end{array}$ & $\begin{array}{l}\text { "People tend not to believe } \\
\text { that I have anything wrong } \\
\text { because I look and sound } \\
\text { so healthy. One of my } \\
\text { major stresses was getting } \\
\text { my doctor to believe that } \\
\text { it's more than stress, } \\
\text { depression, or burn out. } \\
\text { It's easier now that I don't } \\
\text { tell her anything about it I } \\
\text { have to get my medicine } \\
\text { from my other doctor."," } \\
\text { (Participant with AD) }\end{array}$ & $\begin{array}{l}\text { Misdiagnosis is } \\
\text { a possible reason } \\
\text { why obtaining } \\
\text { an accurate } \\
\text { diagnosis is } \\
\text { challenging. }\end{array}$ & $\begin{array}{l}\text { Difficulty obtaining an } \\
\text { accurate diagnosis was } \\
\text { a theme found in the } \\
\text { reports, reported by } 14 \\
\text { of the } 23 \text { participants. } \\
\text { As captured in the } \\
\text { quote, recipients } \\
\text { experienced not being } \\
\text { believed and lack of } \\
\text { knowledge about how } \\
\text { dementia presents in } \\
\text { younger people by } \\
\text { professionals. }\end{array}$ \\
\hline
\end{tabular}




\begin{tabular}{|c|c|c|c|c|c|c|c|}
\hline $\begin{array}{l}\text { Hoppe } \\
\text { (2017) }\end{array}$ & $\begin{array}{l}\text { The } \\
\text { Netherlands }\end{array}$ & $\begin{array}{l}\text { PwYOD (7) } \\
\text { age: NS; } \\
\text { gender: } \quad 4 \\
\text { females, } \quad 3 \\
\text { males. } \\
\text { Family } \\
\text { members } \\
\text { (39), age: } \\
\text { NS; gender: } \\
\text { NS }\end{array}$ & NS & $\begin{array}{l}\text { Semi- } \\
\text { structured } \\
\text { interviews }\end{array}$ & $\begin{array}{l}\text { "I went to the sauna with } \\
\text { my sister-in-law and said } \\
\text { that I was worried. Yes, we } \\
\text { talked about it. That was } \\
\text { four years before the } \\
\text { diagnosis. In that period I } \\
\text { was already worried, and } \\
\text { that is now more than six } \\
\text { years ago. That was in the } \\
\text { beginning and of course } \\
\text { you don't want to know... } \\
\text { (Ellen, 55, partner)" }\end{array}$ & $\begin{array}{l}\text { Recognising the } \\
\text { prodromal } \\
\text { symptoms and } \\
\text { speaking with } \\
\text { family members } \\
\text { about these can } \\
\text { start the journey } \\
\text { to diagnosis. }\end{array}$ & $\begin{array}{l}\text { The paper highlights } \\
\text { the shift in the meaning } \\
\text { of uncertainty in the } \\
\text { pre-diagnostic illness } \\
\text { trajectory of YOD. }\end{array}$ \\
\hline $\begin{array}{l}\text { Johannessen } \\
\text { \& Moeller } \\
(\mathbf{2 0 1 3 )}\end{array}$ & Norway & $\begin{array}{l}\text { PwYOD: } \\
(20) \text { age: } \\
\text { mean } 62 \\
\text { years }(54- \\
67) \text {; gender: } \\
8 \text { females, } \\
12 \text { males }\end{array}$ & NS & $\begin{array}{l}\text { Semi- } \\
\text { structured } \\
\text { Interviews }\end{array}$ & $\begin{array}{l}\text { "'It started when I was } \\
\text { doing a lot of things wrong } \\
\text { at work - I also felt that } \\
\text { something was wrong. My } \\
\text { colleagues at work } \\
\text { experienced it too, as they } \\
\text { told me that it seemed as if } \\
\text { I was struggling and they } \\
\text { asked me if I was tired. I } \\
\text { felt tired also. [Number } \\
\text { 20]' }\end{array}$ & $\begin{array}{l}\text { The quote from } \\
\text { Number } 20 \\
\text { highlights how } \\
\text { symptoms can } \\
\text { be recognised in } \\
\text { the workplace, } \\
\text { and by making } \\
\text { society more } \\
\text { aware of YOD } \\
\text { could better } \\
\text { support these } \\
\text { individuals to } \\
\text { accessing } \\
\text { appropriate help. } \\
\text { Number } 4 \text {, } \\
\text { emphasises the } \\
\text { issues of present }\end{array}$ & $\begin{array}{l}\text { Two main themes } \\
\text { emerged from this } \\
\text { study: (1) the process } \\
\text { towards a dementia } \\
\text { diagnosis, with } \\
\text { subthemes (i) changes } \\
\text { during the prodromal } \\
\text { period (ii) and the } \\
\text { impact of "being } \\
\text { diagnosed; and (2) } \\
\text { fighting for dignity } \\
\text { after being diagnosed } \\
\text { with dementia with } \\
\text { subthemes: } \\
\text { intrapsychic challenges } \\
\text { and (ii) social } \\
\text { challenges. }\end{array}$ \\
\hline
\end{tabular}




\begin{tabular}{|c|c|c|c|c|c|c|c|}
\hline & & & & & $\begin{array}{l}\text { what is to come and it is } \\
\text { quite terrible that I will } \\
\text { suddenly turn out to be, } \\
\text { ugly as it sounds, 'a } \\
\text { second-class citizen'. } \\
\text { [Number 4]" }\end{array}$ & $\begin{array}{ll}\text { stigma } & \\
\text { surrounding } & \\
\text { having } & \text { a } \\
\text { diagnosis } & \text { of } \\
\text { dementia. } & \end{array}$ & \\
\hline $\begin{array}{l}\text { Rabanal, } \\
\text { Chatwin, } \\
\text { Walker, } \\
\text { O'Sullivan } \\
\text { \& Wilkinson } \\
(\mathbf{2 0 1 8 )}\end{array}$ & UK & $\begin{array}{l}14 \text { people } \\
\text { with YOD } \\
\text { aged } \\
\text { between } \\
57 \text { and } 67 \\
\text { years }\end{array}$ & NS & $\begin{array}{l}\text { Interviews. } \\
\text { Five } \\
\text { interviews } \\
\text { were } \\
\text { paired } \\
\text { (person } \\
\text { with } \\
\text { dementia } \\
\text { and their } \\
\text { carer), but } \\
\text { the carer } \\
\text { voices are } \\
\text { not } \\
\text { reported } \\
\text { here. }\end{array}$ & $\begin{array}{l}\text { "The doctors and } \\
\text { consultants were saying, } \\
\text { 'no, you're too young to } \\
\text { have dementia'. At this } \\
\text { time I was about 49. So } \\
\text { their thinking was it could } \\
\text { be depression or stress } \\
\text { because I was still working } \\
\text { at this point. (Participant } \\
\text { 1)" } \\
\text { "[They said] it's early } \\
\text { onset Alzheimer's disease, } \\
\text { just out of the blue like that. } \\
\text { Well I was numb. }\end{array}$ & $\begin{array}{l}\text { Making } \\
\text { clinicians more } \\
\text { aware of YOD } \\
\text { could reduce } \\
\text { delays by not } \\
\text { misattributing } \\
\text { symptoms of } \\
\text { dementia as } \\
\text { psychiatric } \\
\text { disorders. }\end{array}$ & $\begin{array}{l}\text { After seeking medical } \\
\text { help, people reported } \\
\text { that the GP did not } \\
\text { recognise that dementia } \\
\text { could be a cause of the } \\
\text { symptoms and } \\
\text { misattributed the } \\
\text { symptoms to a } \\
\text { psychiatric disorder. } \\
\text { Regardless of how the } \\
\text { diagnosis thas } \\
\text { delivered, there was } \\
\text { unanimity over the } \\
\text { shock of having the } \\
\text { diagnosis confirmed. }\end{array}$ \\
\hline
\end{tabular}




\begin{tabular}{|c|c|c|c|c|c|c|c|}
\hline & & & & & $\begin{array}{l}\text { (Participant 3) ... it was } \\
\text { awful. Ifelt like I was hit by } \\
\text { a sledgehammer... I felt as } \\
\text { though somebody had } \\
\text { pulled the plug out of } \\
\text { everything. (Participant } \\
\text { 5)" }\end{array}$ & $\begin{array}{l}\text { demonstrates the } \\
\text { impact of } \\
\text { receiving a } \\
\text { diagnosis of } \\
\text { YOD which can } \\
\text { be influenced by } \\
\text { how the } \\
\text { diagnosis is } \\
\text { communicated. }\end{array}$ & \\
\hline $\begin{array}{l}\text { Roach, } \\
\text { Drummond } \\
\text { \& Keady } \\
(2016)\end{array}$ & Canada & $\begin{array}{l}\text { Nine } \\
\text { families } \\
\text { made up of } \\
20 \\
\text { participants, } \\
\text { including } \\
\text { nine spousal } \\
\text { pairs, and } \\
\text { two young } \\
\text { adult } \\
\text { families. } \\
\text { PwYOD } \\
(9) \text {; gender: } \\
0 \text { females, } \\
9 \text { males. }\end{array}$ & $\begin{array}{l}7 \text { AD } \\
1 \text { PCA } \\
1 \quad \text { Mixed } \\
\text { Vascular } \\
\text { dementia. }\end{array}$ & $\begin{array}{l}\text { Research } \\
\text { Interviews } \\
\text { with each } \\
\text { of the } \\
\text { families on } \\
\text { two } \\
\text { separate } \\
\text { occasions. }\end{array}$ & $\begin{array}{l}\text { "And again the age factor. } \\
\text { And that's the big deal, that } \\
\text { nobody would say that this } \\
\text { is Alzheimer's or dementia } \\
\text { at this age". }\end{array}$ & $\begin{array}{l}\text { Increasing } \\
\text { awareness of } \\
\text { YOD can reduce } \\
\text { unnecessary } \\
\text { delays to } \\
\text { receiving a } \\
\text { diagnosis and } \\
\text { accessing the } \\
\text { support needed. }\end{array}$ & $\begin{array}{l}\text { Lack of information } \\
\text { during the diagnostic } \\
\text { experience and doubt } \\
\text { from healthcare } \\
\text { professionals about the } \\
\text { diagnosis were themes } \\
\text { found in their study. }\end{array}$ \\
\hline $\begin{array}{l}\text { Wawrziczny } \\
\text { et al (2016) }\end{array}$ & France & $\begin{array}{l}\text { PwYOD } \\
(16) \text {, gender } \\
\text { NS and (16) }\end{array}$ & $\mathrm{AD}$ & $\begin{array}{l}\text { Semi- } \\
\text { structured } \\
\text { Interviews }\end{array}$ & $\begin{array}{l}\text { "'Couple 15: I didn't see } \\
\text { the onset of the disease } \\
\text { because I was always }\end{array}$ & $\begin{array}{l}\text { The quotes from } \\
\text { couple } 15 \text { and } \\
\text { couple }\end{array}$ & $\begin{array}{l}\text { The 'need to know' the } \\
\text { cause of the dementia, } \\
\text { and after diagnosis, the }\end{array}$ \\
\hline
\end{tabular}




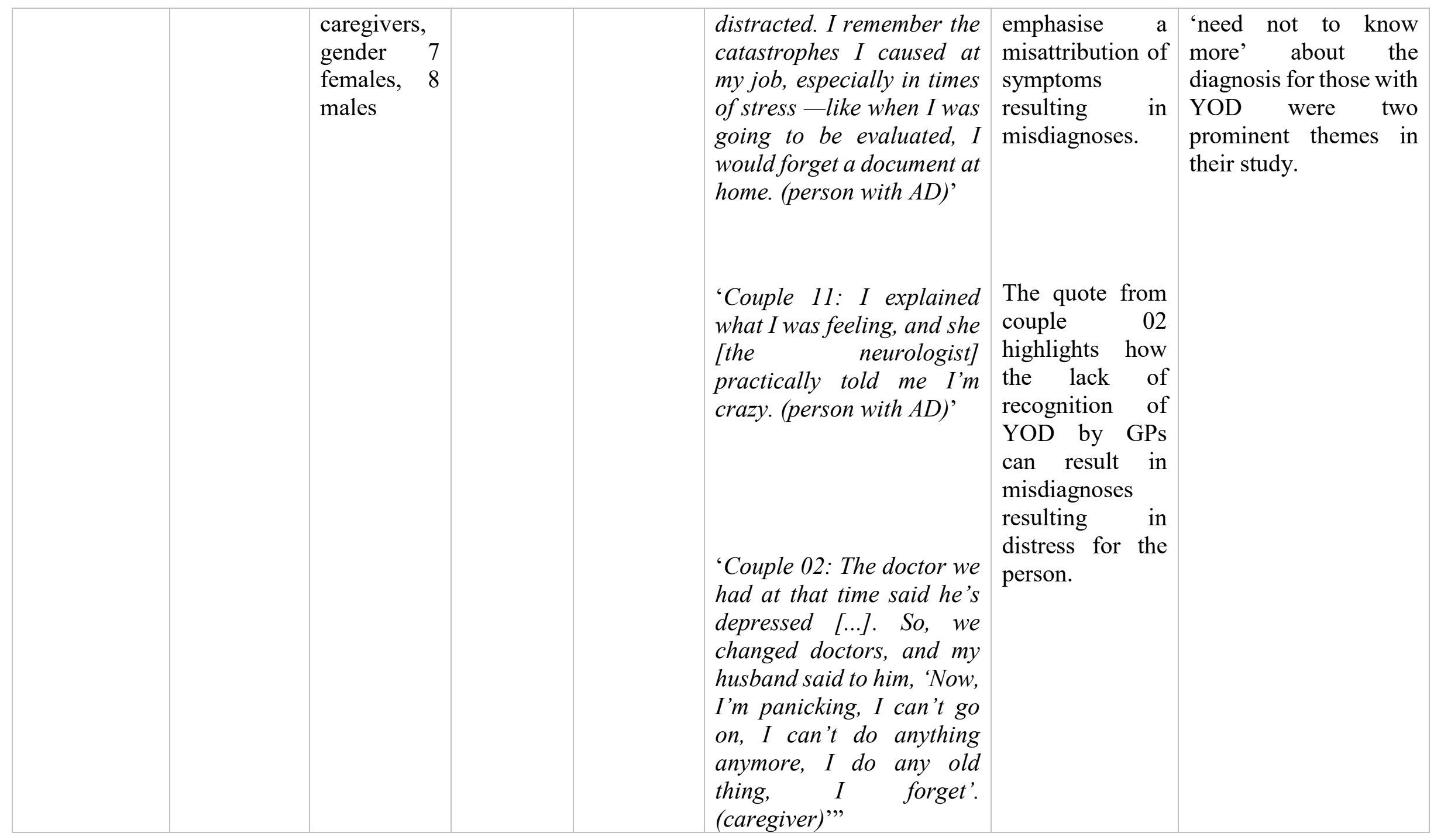


Table 3: Main characteristic of the eight included studies. NS means “not stated”. AD = Alzheimer's disease, PCA = Posterior Cortical Atrophy,

$\mathrm{FTD}=$ Frontotemporal dementia, BvFTD = behavioural variant of frontotemporal dementia, $\mathrm{HD}=$ Huntington's disease, $\mathrm{MCI}=\mathrm{Mild}$ Cognitive

Impairment. 


\section{Findings}

The research papers found in the literature search were read and cross-validated to explore which similarities, differences and key issues were most frequently reported. Quality Assessment using Walsh and Downe's criteria for appraising qualitative research studies (Table 3; Walsh \& Downe, 2006) demonstrated that all papers scored above 9/12 according to their criteria (see Table 3). Through familiarising ourselves with the quotes and interpretations in the highlighted papers, we identified overlapping themes across studies about people's experiences and the quality of the diagnostic process which we have grouped accordingly:

\section{The journey to diagnosis - delay in accessing help}

Hoppe (2017) illustrated that individuals and their families initially tried to ignore early prodromal symptoms as they wished to lead life as normal or to not attribute the possible symptoms to dementia and this avoidance may have led to not seeking help for early symptoms: “But you also ignore it (the dementia), you don't want to see it.".

Hoppe used the idiom "ignorance is bliss" to describe why people with YOD may not take action to determine a diagnosis. In other words, although most had an existential awareness of an underlying condition, maintaining uncertainty allowed hope to remain.

Griffin et al (2015) emphasised that, for some, inadvertently denying initial symptoms could alternatively be a result of a dementia sub-type in which lack of awareness is a characteristic feature. For example, one participant with behavioural variant fronto-temporal dementia $(\mathrm{Bv}$ FTD) did not seem to recognise any changes in his own behaviour and showed a lack of emotional reaction and reflection on his diagnosis of YOD. His feelings, on diagnosis, 
reflected a sense of bewilderment with an awareness of change not recognised as self, "this is not me". Here the issue was rather that the individual had difficulty in fully appreciating and understanding the impact of the diagnosis on himself. Failure to recognise altered behaviours, could inadvertently contribute to a delayed diagnosis and access to timely support.

\section{Misattribution of symptoms - delay to diagnosis}

Under-recognition of prodromal symptoms as dementia by clinicians was identified in most research papers found in the search. Participants in Harris' (2004) study suggested that as those with YOD in their study looked physically healthy, this resulted in doctors not taking their concerns as seriously. Complaints of memory problems in healthy older adults are likely to prompt investigation for dementia, but the quotes from Harris' participants demonstrate that psychiatric disorders were more immediately considered as the primary diagnosis. Furthermore, the reports made by participants in Roach et al (2016) highlight how clinicians and healthcare professionals doubted dementia as a cause, specifically because the person was young.

Two studies (Harris 2004: Rabanal 2018) confirm that misattribution of presenting symptoms as psychiatric disorders, particularly depression or 'stress' is common in younger adults.

The participants in Harris (2004) reported their frustration that they had to emphasise to clinicians that their symptoms were more than simply being burnt out. The fact that the individual was still working seemed to influence the clinicians. However, it is not uncommon for dementia in younger people to present with non-cognitive symptoms (e.g. psychosis, 
mood disturbances, personality changes) and for day-to-day activities and function to be well-preserved.

Conversely, Johannessen and Moeller (2013) highlight how those with YOD had difficulties getting health professionals to listen to what was wrong with them. Symptoms were dismissed despite evidence of difficulties with day-to-day tasks or in the workplace being noticed by others.

\section{Communicating diagnosis - impact of diagnosis}

Language used

Some of the papers reviewed have highlighted that the communication style some health professionals' use when discussing the diagnostic process, (i.e. tests and investigations) and relaying the diagnosis require greater sensitivity and should be tailored appropriately. For example, the way in which the diagnosis was given to a patient and their supporters lacked empathy and was perceived as traumatic in Beattie et al's (2004) study: "It was very blunt, yeah. It was brutal, that's the only word for it." (YP 14; Beattie et al., 2004). The diagnostic testing was also reported as 'baffling' by the participants in Beattie's study (2004), so much so that one individual and their carer were left feeling incompetent, distressed, and subsequently unprepared for the receipt of distressing news. In particular, this participant felt the diagnostic assessment lacked in structure, with the assessments starting "from being casual to an extreme" (YP 14; Beattie et al., 2004), highlighting how the format of assessments and the communication of assessments may need to be more consist, to prevent the people from viewing aspects as unprofessional or baffling. 
Wawrziczny, Pasquier, Ducharme, Kergoat, \& Antoine, (2016) found that receiving a diagnosis of dementia for a younger person could be reassuring, by ending a period of doubt, but also destabilising, by breaking the equilibrium that had been maintained to date. One person reported that “as long as they haven't made a diagnosis, me, I say [addressing her spouse with AD], 'Maybe you're depressed, huh?' [...] But then we won't be able to hide anymore, once they've said it. (caregiver) (Wawrziczny et al., 2016). This quote also highlights how knowing the cause of the symptoms can provide a sense of control in managing feelings.

Rabanal et al (2018) concluded that regardless of how the diagnosis was delivered, there was unanimity over the shock of receiving the dementia diagnosis. More so, it was apparent in their study that the amount of supporting documentation and information that participants were given at the point of diagnosis, sometimes caused them to feel overwhelmed, with one participant feeling 'bombarded' with leaflets. Having the opportunity to see someone face-toface who can offer emotional support immediately after diagnosis was also highlighted as something that would be highly beneficial.

\section{Discussion}

The reports in the studies from the literature search, provide important insights into the personal experiences of younger people who receive a diagnosis of dementia by illustrating how individuals understand and make sense of the changes within themselves, and the impact the diagnosis has on their lives. There is a lack of research focused on the diagnostic experience in younger adults with dementia, with only eight papers found in the literature search where the diagnostic experience was partially discussed. 
Under-recognition of and awareness about dementia in younger people, together with misattribution of symptoms are both major contributing factors to the much longer delays in receiving a diagnosis for a younger adult compared to older adults. Luscombe, Brodaty, \& Freeth (1998) reported that for 110 people diagnosed with YOD the mean length of time before diagnosis was 3.4 years $(\mathrm{SD}=2.8)$. More recent statistical reports (Draper et al., 2016), demonstrate a time to diagnosis of 4.4 years in younger adults with dementia, compared with 2.2 years in late onset dementia (van Vliet et al., 2013). Williams (2001) highlighted that most younger adults experience chaotic pathways into care, with many seeing 2-5 different specialist consultants before receiving a definitive diagnosis. Although seeing multiple specialist consultants potentially adds to the delay in confirming diagnosis, it could be argued that this is unavoidable when complexity and atypical presentations necessitate extensive investigation and assessment. The reports outlined here, provide insight into delays, suggesting that these can be person, age- and/or diagnosis-specific. With regard to factors out with an individual's personal preference to seek help, initial misdiagnosis and lack of recognition of presenting symptoms were common self-reported experiences.

For example, most individuals presented first to their GP in primary care. It is of concern that many participants in the studies suggested and experienced their GPs and secondary care doctors to be lacking in the knowledge that dementia is a condition that can affect younger people: "The doctors and consultants were saying, 'no, you're too young to have dementia'. At this time I was about 49 ..." (Participant 1; Rabanal et al., 2018). Making the diagnosis, or making a decision to refer, is often contingent on enquiry about additional unusual or atypical symptoms, taking a history from an informant, and a knowledge of presenting symptoms that often differ from late onset disease. Lack of familiarity and enquiry can lead to a dismissal of symptoms. It can also cause a mis-attribution of the symptoms to primary 
psychiatric disorders. This can be accompanied, as illustrated here, by frustration for patients and a sense of having to fight to be heard. The high rates of psychiatric misdiagnosis are driven by the significant overlap in symptoms of neurodegenerative disease especially bvFTD and psychiatric disorders (Shinagawa et al., 2014). In one study with large patient sample size, $28 \%$ of individuals had a prior incorrect psychiatric diagnosis (Woolley, Khan, Murthy, Miller, \& Rankin, 2011). They found that across groups, depressive disorders and bipolar affective disorder were the most frequent misdiagnoses. Also, a diagnosis of schizophrenia was not uncommon. Rates ranged from $<12 \%$ in those with atypical presentations, e.g. prominent language, speech or movement disorders, and up to $52 \%$ in those with bvFTD (Woolley et al., 2011). Over 50\% of younger patients waited up to 3 years before the diagnosis was revised, which therefore results in delays in receiving an accurate diagnosis.

The studies found in the review confirm that communication style, language and clarity of explanation, particularly with regard to the often-numerous tests and procedures required for younger adults, have a significant effect on patient welfare and empowerment.

Thus, a sensitive, collaborative and enabling approach to both assessment and disclosure of the diagnosis is crucial, with ample opportunity for discussion as and when an individual feels ready to know more. The complexity of judging how much a person and their family wish to know about the diagnosis has been echoed in other qualitative studies of all-age dementia. Information may be empowering for some, but rejected by others who may choose 'not to know" (Bunn et al., 2012). The National Institute of Clinical Excellence (NICE) states that "people should be told their diagnosis as clearly and honestly as possible" to "plan effectively for their future" and access treatment and support (National Institute for Health and Clinical Excellence, 2006). The personal experience of YPD quoted here emphasises that 
there are gaps in addressing peoples' cognitive needs for information and emotional needs for empathy. It is inevitable that addressing a younger person's needs for information about their complex assessment, understanding their emotional reactions to the diagnosis, providing them with information about the future, and building a meaningful life with dementia would differ depending on the age of onset and the specific dementia sub-type. No practical guidance regarding communication of diagnosis in younger people currently exists.

Importantly, an apparent lack of overt initial reaction may not necessarily reflect the severity of impact that the diagnosis has on the individual. Ensuring that immediate emotional support is available was regarded as more beneficial in the short-term than providing information leaflets on dementia and possibly post-diagnostic support services. A template for good practice in diagnosis has been developed by the Young Dementia Network (https://www.youngdementiauk.org/young-onset-dementia-pathwaywhich) and involves a fresh approach to provide continuity of care and support at and before diagnosis through the provision of a specialist key worker. The YDN recommend that the key worker should (a) have specialist knowledge, skills and experience of the impact on YOD, including knowledge and understanding of rarer forms of dementia, as well as the impact of diagnosis at a younger age for the person diagnosed and their family. They should also (b) provide information, practical and emotional support for family members and (c) provide continuity of support, and enable the person living with YOD to understand their condition and actively engage in their care plan and journey. The key worker should also (d) act as a coordinator of services, organisations and people, helping to connect the person living with YOD to local group and they should be available through a variety of organisations depending on local infrastructure such as primary care, voluntary sector or be based within local mental health teams or neurology services. Providing this initial support through a key worker would provide the 
needed emotional support immediately following diagnosis that was highlighted as an issue in the literature search.

The British Psychological Society (Watts, McCabe, \& Guss, 2018), has recently released advice for clinicians on how best to communicate a diagnosis of dementia recommending that it be person-centred, taking account of an individual's expectations, preparedness and expressed wishes and consent should be sought about these. Although these suggestions apply broadly to dementia across all ages, ensuring these principles are considered when diagnosing younger adults may be more challenging. For example, language variants, visuospatial variants and behavioural change are more common in younger people and understanding of the user perspective can be hard to gain. Australia Dementia have published helpful guidance on better ways to communicate with younger people with dementia (Dementia Australia, 2017), including (1) developing strategies to improve understanding and (2) seeking ways to encourage communication and expression when language and communication are often more significantly affected.

Additionally, good practice in pre-assessment counselling (La Fontaine, Buckell, Knibbs, \& Palfrey, 2014) and establishing informed consent sets the scene for successful future engagement with services and enables people to adapt in such a way that the advantages of early diagnosis are maximised. People with dementia have explicitly stated that they have the right of a timely and accurate diagnosis (Dementia Action Alliance, 2018), and this is essential for people who are still of working age, with family commitments and financial concerns. 
Finally, it is perhaps worrying that although two of the articles found in the literature search were published more than 10 years ago (Harris, 2004; Beattie, 2004) the themes identified remain consistent with more recent reports (Griffin et al, 2015; Wawrziczny et al., 2016), emphasising the recurrence and persisting nature of the issues raised. Furthermore, the research described was conducted in a variety of European countries and North America indicating that the issues highlighted are universal and could benefit from international consensus.

\section{Implications for Research and Practice}

\section{Practice}

These valuable insights into the personal experiences of receiving a diagnosis of YOD have significant implications for health care professionals working in the field. Implicit within these findings is the need for increased awareness of the impact a diagnosis of dementia has on younger adults in relation to their work, relationships and personal circumstances. It is hoped that reducing delays and avoiding misdiagnoses could potentially lead to a better adjustment to the diagnosis of dementia.

Improving recognition of symptoms by education of key professionals, clarifying pathways into care and identifying local experts with specialist expertise remain key goals. In 2018, the Young Dementia Network in the UK, produced a diagnostic algorithm to support General Practioners, (GPs) (https://www.youngdementiauk.org/gp-decision-making-guide) in identifying possible early symptoms of YOD, and the steps and checks GPs should undertake. Similarly, a YOD care pathway (https://www.youngdementiauk.org/young-onsetdementia-pathway) bringing together the experience and expertise of people affected by YOD and the people who work with and support them, identified a series of 
recommendations to guide policy makers, commissioners and practitioners in designing and delivering services which empower and meet the needs of younger people with dementia and their families. The pathway identifies key standards about the process from pre-diagnosis and transition to end of life care.

\section{Research}

No guidelines about best practice in diagnosis of YOD currently exist. General guidelines for dementia (e.g. NICE) are presently not informed by the lived experience from those directly affected. While most clinicians would agree that a truly collaborative and person-centred approach to diagnosis is crucial, limited evidence is available to support how this could be best achieved. YPD have specific needs, arising from their stage of life and the consequence of diagnosis at a younger age has a devastating impact on life trajectory, relationships and role.

Putting the YPD at the centre of this process to understand what works best to improve the patient experience would mark an advance in approach and policy. A deeper enquiry into the experience of receiving a diagnosis of dementia in younger adults, where both people with dementia and their families are included is necessary (Stamou et al., 2018). A consensus Delphi study of people living with YOD, and their families is the current focus of our own research, where our goal is to capture experiences of the diagnostic process from YPD and their supporters, and most importantly use their expertise to inform how and where improvements should be made. This review has provided theoretical and methodological guidance in steering the focus of questions in the first round of that Delphi study. 


\section{Conclusion}

In conclusion, the literature highlights that there is scope to improve the process surrounding diagnosis for YPD, particularly in relation to the journey to diagnosis, misattribution of symptoms and communicating the diagnosis. The Angela Project, funded by the Alzheimer's Society is a current project which focuses on improving the quality and accuracy of diagnosis and support and services for YOD. This review has illustrated the importance of the voice of YPD and their supporters in shaping good practice.

\section{Acknowledgements}

The authors would like to thank the Alzheimer's Society, YoungDementia UK and Dementia UK for their significant support as external partners of this study. Special mention should also go to The Angela Project's Public and Patient Involvement (PPI) Group, and Steering Committee for their helpful suggestions.

\section{References}

Bunn, F., Goodman, C., Sworn, K., Rait, G., Brayne, C., Robinson, L., ... Iliffe, S. (2012). Psychosocial Factors That Shape Patient and Carer Experiences of Dementia Diagnosis and Treatment: A Systematic Review of Qualitative Studies. PLoS Medicine, 9(10). https://doi.org/10.1371/journal.pmed.1001331

Dementia Action Alliance. (2018). No Title. Retrieved March 29, 2019, from https://www.dementiaaction.org.uk/nationaldementiadeclaration

Dementia Australia. (2017). Language and communication.

Draper, B., Cations, M., White, F., Trollor, J., Loy, C., Brodaty, H., ... Withall, A. (2016). Time to diagnosis in young-onset dementia and its determinants: the INSPIRED study. International Journal of Geriatric Psychiatry, 31(11), 1217-1224. https://doi.org/10.1002/gps.4430 
Greenhalgh, T., \& Peacock, R. (2005). Effectiveness and efficiency of search methods in systematic reviews of complex evidence: Audit of primary sources. British Medical Journal, 331(7524), 1064-1065. https://doi.org/10.1136/bmj.38636.593461.68

Greenwood, N., \& Smith, R. (2016). The experiences of people with young-onset dementia: A meta-ethnographic review of the qualitative literature. Maturitas, 92, 102-109. https://doi.org/10.1016/j.maturitas.2016.07.019

Griffin, J., Oyebode, J. R., \& Allen, J. (2016). Living with a diagnosis of behavioural-variant frontotemporal dementia: The person's experience. Dementia (London), 15(6), 16221642. https://doi.org/10.1177/1471301214568164

Harris, P. B. (2004). The Perspective of Younger People with Dementia: Still an Overlooked Population. Social Work in Mental Health, 2(4), 17-36. https://doi.org/10.1300/J200v02n04

Harvey, R. J., Skelton-Robinson, M., \& Rossor, M. N. (2003). The prevalence and causes of dementia in people under the age of 65 years. Journal of Neurology, Neurosurgery, and Psychiatry, 74(9), 1206-1209. https://doi.org/10.1136/jnnp.74.9.1206

Jonas-Simpson, C. M. (2003). The experience of being listened to: A human becoming study with music. Nursing Science Quarterly, 16(3), 232-238. https://doi.org/10.1177/0894318403252452

La Fontaine, J., Buckell, A., Knibbs, T., \& Palfrey, M. (2014). Clinical Psychology in the Early Stage Dementia Care Pathway. Retrieved from https://www1.bps.org.uk/system/files/user-files/DCP Faculty for the Psychology of Older People \%28FPoP\%29/public/clinical_psychology_in_early_stage_dementia_care_pathway.pdf

Luscombe, G., Brodaty, H., \& Freeth, S. (1998). Younger people with dementia: Diagnostic issues, effects on carers and use of services. INTERNATIONAL JOURNAL OF GERIATRIC PSYCHIATRY, 13(5), 323-330. https://doi.org/10.1002/(SICI)10991166(199805)13:5<323::AID-GPS768>3.3.CO;2-F

Mayrhofer, A., Mathie, E., McKeown, J., Bunn, F., \& Goodman, C. (2018). Age-appropriate services for people diagnosed with young onset dementia (YOD): a systematic review. Aging and Mental Health, 22(8), 927-935. https://doi.org/10.1080/13607863.2017.1334038

Mercy, L., Hodges, J. R., Dawson, K., Barker, R. A., \& Brayne, C. (2008). Incidence of early-onset dementias in Cambridgeshire, United Kingdom. Neurology, 71(19), 14961499. https://doi.org/10.1212/01.wnl.0000334277.16896.fa

Moher, D., Liberati, A., Tetzlaff, J., \& Altman, D. G. (2010). Preferred reporting items for systematic reviews and meta-analyses: The PRISMA statement. International Journal of Surgery, 8(5), 336-341. https://doi.org/10.1016/j.ijsu.2010.02.007

National Institute for Health and Clinical Excellence. (2006). Dementia.

Roach, P., Drummond, N., \& Keady, J. (2016). 'Nobody would say that it is Alzheimer's or dementia at this age': Family adjustment following a diagnosis of early-onset dementia. 
JOURNAL OF AGING STUDIES, 36, 26-32.

https://doi.org/10.1016/j.jaging.2015.12.001

Roach, P., Keady, J., \& Bee, P. (2012). “It"s easier just to separate them': Practice constructions in the mental health care and support of younger people with dementia and their families. Journal of Psychiatric and Mental Health Nursing, 19(6), 555-562. https://doi.org/10.1111/j.1365-2850.2011.01836.x

Rohra, H. (2016). Dementia Activist: Fighting for Our Rights. London: Jessica Kingsley Publishers.

Rosness, T. A., Engedal, K., \& Chemali, Z. (2016). Frontotemporal Dementia: An Updated Clinicians Guide. Journal of Geriatric Psychiatry and Neurology, 29(5), 271-280. https://doi.org/10.1177/0891988716654986

Rossor, M. N., Fox, N. C., Mummery, C. J., Schott, J. M., \& Warren, J. D. (2010). The diagnosis of young-onset dementia. The Lancet Neurology, 9(8), 793-806. https://doi.org/10.1016/S1474-4422(10)70159-9

Shinagawa, S., Nakajima, S., Plitman, E., Graff-Guerrero, A. Mimura, M., Nakayama, K., \& Miller, B. L. (2014). Psychosis in frontotemporal dementia. Journal of Alzheimer's Disease : JAD, 42(2), 485-499.

Stamou, V., La Fontaine, J., Oyebode, J., Jones, B., Gage, H., O’Malley, M., ... Carter, J. (2018). The ANGELA Project: improving diagnosis and post-diagnostic support for younger people with dementia and their families/supporters. FPOP, (142). https://doi.org/10.1093/bjsw/bcs140.

Svanberg, E., Spector, A., \& Stott, J. (2011). The impact of young onset dementia on the family: A literature review. International Psychogeriatrics, 23(3), 356-371. https://doi.org/10.1017/S1041610210001353

van Vliet, D., de Vugt, M. E., Bakker, C., Pijnenburg, Y. a L., Vernooij-Dassen, M. J. F. J., Koopmans, R. T. C. M., \& Verhey, F. R. J. (2013). Time to diagnosis in young-onset dementia as compared with late-onset dementia. Psychological Medicine, 43(2), 423 432. https://doi.org/10.1017/S0033291712001122

Vernooij-Dassen, M. (2006). Receiving a diagnosis of dementia: The experience over time. Dementia, 5(3), 397-410. https://doi.org/10.1177/1471301206067114

Vieira, R. T., Caixeta, L., Machado, S., Cardoso Silva, Adriana Nardi, A. E., Arias-Carrión, O., \& Giovanni Carta, M. (2013). Epidemiology of early-onset dementia: a review of the literature. Clinical Practice \& Epidemiology in Mental Health, 9(1), 88-95. https://doi.org/10.2174/1745017901309010088

Walsh, D., \& Downe, S. (2006). Appraising the quality of qualitative research. Midwifery, 22(2), 108-119. https://doi.org/10.1016/j.midw.2005.05.004

Watts, S., McCabe, R., \& Guss, R. (2018). Communicating a diagnosis of dementia. British Psychological Society: Faculty for the Psychology of Older People ( FPOP). https://doi.org/http://dx.doi.org/10.1027/1015-5759/a000054

Wawrziczny, E., Pasquier, F., Ducharme, F., Kergoat, M.-J., \& Antoine, P. (2016). From 
'needing to know' to 'needing not to know more': an interpretative phenomenological analysis of couples' experiences with early-onset Alzheimer's disease. SCANDINAVIAN JOURNAL OF CARING SCIENCES, 30(4), 695-703. https://doi.org/10.1111/scs.12290

Williams, T., Dearden, A. M., \& Cameron, I. H. (2001). From pillar to post - a study of younger people with dementia. Psychiatric Bulletin, 25(10), 384-387. https://doi.org/10.1192/pb.25.10.384

Woolley, J. D., Khan, B. K., Murthy, N. K., Miller, B. L., \& Rankin, K. P. (2011). The diagnostic challenge of psychiatric symptoms in neurodegenerative disease; rates of and risk factors for prior psychiatric disgnosis in patients with early neurodegenerative disease. J Clin Psych, 72(2), 126-133. https://doi.org/10.4088/JCP.10m06382oli.The 